\title{
Production and immune response of recombinant Hsp60 and Hsp70 from the salmon pathogen Piscirickettsia salmonis
}

\author{
${ }^{1}$ VIVIAN WILHELM, ${ }^{1}$ CRISTIÁN SOZA, ${ }^{1}$ RODRIGO MARTÍNEZ, ${ }^{1,2,4}$ MARIO \\ ROSEMBLATT, ${ }^{1,2,4}$ LUIS O. BURZIO and ${ }^{1,2,3,4}$ PABLO D.T. VALENZUELA
}

\author{
${ }^{1}$ Fundación Ciencia para la Vida, ${ }^{2}$ Universidad Andrés Bello, ${ }^{3}$ Pontificia Universidad Católica de Chile e \\ ${ }^{4}$ Instituto Milenio de Biología Fundamental y Aplicada, Av. Zañartu 1482, Santiago, Chile
}

\begin{abstract}
We have isolated and sequenced the genes encoding the heat shock proteins 60 (Hsp60) and 70 (Hsp70) of the salmon pathogen Piscirickettsia salmonis. The sequence analysis revealed the expected two open reading frames that encode proteins with calculated molecular weights of 60,060 and 70,400. The proteins exhibit a $70-80 \%$ homology with other known prokaryotic Hsp60 and Hsp70 sequences. The coding regions have been expressed in E. coli as thioredoxin fusion proteins. Both recombinant proteins were shown to elicit a humoral response when injected intraperitoneally in Atlantic salmon and also conferred protection to fish challenged with $P$. salmonis. The present data will facilitate further studies on the involvement of heat shock proteins in protective immunity of fish to infection by $P$. salmonis and their potential use in recombinants vaccines against this intracellular pathogen.
\end{abstract}

Key terms: Piscirickettsia salmonis, Hsp60, Hsp70, groEL, dnaK, immune response

\section{INTRODUCTION}

The obligate intracellular bacterium Piscirickettsia salmonis is the etiological agent of salmonid rickettsial septicemia (SRS), a disease responsible for extensive mortality in the Chilean salmon industry (Branson and Nieto, 1991; Fryer et al., 1990; Lannan and Fryer, 1993; Fryer and Mauel, 1997). This pathogen has also been identified in the Northern hemisphere (House et al., 1999; Brocklebank et al., 1993; Jones et al., 1998).

Recently, SRS has been partially controlled through the use of antibiotics, although they are not fully effective and have problems derived from their toxicity and generation of resistance. Vaccines have proven to work well in preventing infection. However, no effective vaccines are currently commercially available against $P$. salmonis. This pathogen grows very slowly in cell lines; it takes 15 to 20 days to develop a full cytopathic effect, making it difficult to process large quantities of cells and to separate them from host material.

In our search for potential vaccine candidates we have started the identification and study of $P$. salmonis genes coding for proteins with potential application in the production of an effective vaccine to control SRS. In addition to the membrane bound transglycosylase and transferrin binding protein (Wilhelm et al., 2004), we have directed our efforts toward the $P$. salmonis heat shock protein genes. It is well known that pathogen-derived Hsp are targets used by the host immune response to control infection. The Hsp serve as important antigens inducing very strong 
cellular and humoral immune responses (Kaufman, 1990, 1991; Kaufman et al., 1990). Immune responses to Hsp have been observed in infectious diseases caused by bacteria, protozoa, fungi and nematodes (Zügel and Kaufman, 1999).

We report here on the isolation, sequencing, and expression of the $P$. salmonis Hsp60 (groEL) and Hsp70 (dnaK) genes and the ability of the recombinant proteins in raising an antibody response in salmon.

\section{MATERIALS AND METHODS}

\section{Cell cultures.}

Inoculates of the Chinook salmon embryo cell line CHSE-214 (ATCC 1681) maintained in liquid nitrogen were thawed, pelleted, resuspended and cultured for 7 days or until confluence in $60 \mathrm{ml}$ of complete MEM (Gibco BRL) supplemented with non-essential amino acids, glutamine and $5 \%$ fetal bovine serum (GIBCO BRL), in $\mathrm{T} 175$ flasks at $16^{\circ} \mathrm{C}$.

\section{Bacterial strains and plasmids.}

E. coli strains NovaBlue and BL21 (DE3), used for cloning and expression respectively, were obtained from Novagen.

Inoculates of $P$. salmonis LF-89 (ATCC VR1361), each containing approximately 1 $\mathrm{x} 10^{8}$ bacteria $/ \mathrm{ml}$, were brought to room temperature, added to flasks containing salmon cells, and incubated overnight at $16^{\circ}$ C. The medium was then replaced by $50 \mathrm{ml}$ of fresh complete MEM supplemented with non-essential amino acids, glutamine and FBS 5\%, and cultured for 10-14 days at $16^{\circ}$ C. Periodic checks of the degree of cytolysis were performed. Cultures were considered ready for harvesting or propagation when almost $100 \%$ of the cells were cytopathic. Cells adhering to the flask walls were scraped, centrifuged twice at $150 \mathrm{xg}$, and the second supernatant was collected as the semi-purified fraction of $P$. salmonis. Further purification was performed according to Miquel et al., (2003).
The plasmids pET32a (Novagen), pET21a and pGEMT (Promega) were propagated in NovaBlue cells in medium Luria Broth (LB) with $100 \mu \mathrm{g} / \mu \mathrm{l}$ ampicillin at $37^{\circ} \mathrm{C}$. E. coli BL21(DE3) cells transformed by pET32a or pET21a were grown in LB with $100 \mu \mathrm{g} / \mathrm{ml}$ ampicillin.

\section{Cloning of the Hsp60 and Hsp70 coding regions.}

Genomic DNA was extracted from the purified fraction of $P$. salmonis using Binder's procedure (1995) as described previously (Wilhelm et al., 2003). Coding regions of Hsp60 and Hsp70 were isolated by PCR amplification using specific primers based on information deduced from the sequence of a genomic library obtained in our laboratory (Valenzuela et al., unpublished results). The sequence of the primers is shown in Table I.

Amplified products were purified employing the Qiaquick PCR purification kit (Qiagen), ligated to pGEMT at $14^{\circ} \mathrm{C}$ in the presence of T4 DNA ligase and used to transform NovaBlue competent cells. Positive clones were selected by blue/white screening using lac $Z \alpha$-complementation.

\section{DNA sequencing.}

The Hsp60 and Hsp70 coding sequences were obtained employing Sanger's dideoxy procedure (1977) using M13 primers. Products were separated by capillary electrophoresis in an ABI 310 Genetic Analyzer (Applied Biosystem Inc.). The $P$. salmonis Hsp60 and Hsp70 coding sequences are registered in the Gene Bank data base under accession numbers AY686756 and AY686757 respectively.

\section{Protein production in E. coli.}

The Hsp60 and Hsp70 coding regions previously cloned in pGEM-T were subcloned in pET32a or pET21a. The plasmids of the recombinant clones were used to transform E. coli BL21(DE3) competent cells. Expression of recombinants was induced by incubation in LB with $1 \mathrm{mM}$ IPTG. Recombinant proteins were purified 
by a Ni-agarose column (Qiagen). Protein concentration was measured using the Micro BCA kit (Pierce). Protein analysis was performed in PAGE-SDS gels according to Laemmli (1970).

\section{Monoclonal antibody production.}

Two-month-old female BALB/c mice were injected intraperitoneally three times at 3week intervals with $50 \mu \mathrm{g}$ of recombinant proteins Hsp60 or Hsp70 diluted in PBS and emulsified with Freund adjuvant. Ten days after the final injection, the animals were bled from the tail to obtain serum. The humoral response against the recombinant proteins was determined by an ELISA according to Jamett et al., (2001). To produce hybridoma, spleen cells from the immunized mice with the highest titer against the recombinant proteins were isolated and fused with NS0/2 mouse myeloma cells according to the general procedure used by Köhler and Milstein (1975) with minor modifications as described previously (Jamett et al., 2001).

\section{Immunization of salmon.}

A group of 104 Salmo salar with an average weight of 18 grams were tagged for group identification and injected intraperitoneally with $200 \mu \mathrm{l}$ of an oil-water emulsion containing $10 \mu \mathrm{g}$ of each recombinant $\mathrm{Hsp} 60$ and $\mathrm{Hsp} 70$. The fish were maintained at $13^{\circ} \mathrm{C}$ under controlled conditions of oxygenation, feeding, and water flow in 4 tanks. Non-immunized control fish were maintained in the same tanks. Serum from some of the treated and control fish was obtained 3 months after vaccination, and the immune response against the recombinant proteins was analyzed by ELISA.

\section{Challenge.}

After 625 degree days, a tank containing 13 vaccinated fish, 13 adjuvant injected fish, and 13 control non-vaccinated fish was challenged with a dose of $P$. salmonis equivalent to 2XLD50. Mortality of fish was registered periodically and dead fish were analyzed to confirm that SRS was the cause of mortality. LD50 was previously determined by analyzing cumulative mortality of intraperitonally injected fish with serial dilution of $P$. salmonis. The effectiveness of the vaccine was determined by the relative percent survival (RPS), which was calculated as follows: RPS $=[1-$ (\% mortality of test group $\div \%$ mortality of control group)] x $100 \%$.

\section{Western blot analysis.}

Recombinant Hsp60 and Hsp70 or wholecell protein obtained from $P$. salmonis were separated by PAGE-SDS gel electrophoresis, transferred to nitrocellulose (Towbin et al., 1979 ) and analyzed with a dilution of anti-P. salmonis rabbit polyclonal serum, specific monoclonal antibodies or with a 1:200 dilution of serum obtained from immunized salmon. The blots were developed with an anti-mouse $\operatorname{IgG}$ conjugated to alkaline phosphatase, or an anti-rabbit $\mathrm{IgG}$ conjugated to alkaline phosphatase. Incubation with a monoclonal antibody against salmon IgM was included in the analysis of salmon serum.

\section{ELISA.}

ELISA assays were carried out according to Aguayo et al. (2002) with minor modifications, using recombinant Hsp60 and $\mathrm{Hsp} 70$ as antigens and dilutions of serum from immunized salmon. Incubation with an anti-salmon IgM monoclonal was included before developing the reaction with anti-mouse IgG conjugated to alkaline phosphatase.

\section{RESULTS AND DISCUSSION}

1. Isolation of Hsp60 and Hsp70 coding regions of $\mathrm{P}$. salmonis.

Our laboratory has sequenced approximately $90 \%$ of the $P$. salmonis genome. The sequences of the contigs has allowed us to identify about 1,500 genes that are being arranged in a circular genome of about $2 \times 10^{6}$ base pairs. Genes 
corresponding to heat shock proteins Hsp60 and Hsp70 were identified by comparison to sequences of genomes of phylogenetically related organisms such as Pseudoalteromonas haloplankitis for Hsp60 and Legionella pneumophila for Hsp70. Figure 1 shows that the region coding for Hsp60 is found in contigs 291 (1,072 base pairs) and 750 (566 base pairs). Contig 291 includes from the 5' end up to nucleotide 1004 and contig 750 comprises the coding region for the carboxyl end of the protein, from nucleotide 1070 to nucleotide 1,636.
This was confirmed by amplifying a fragment of 1,651 base pairs (Fig. 1) with primers $\mathrm{p} 1$ and $\mathrm{p} 2$ (Table I). This fragment was cloned into pGEM-T and sequenced. An open reading frame of 1,638 base pairs codifies a protein of 546 amino acids (Fig. 2) corresponding to a protein of 60,060 daltons. A high degree of homology was found when comparing this protein with Hsp60 of other microorganisms (Fig. 2). Comparative analysis of Hsp60 of $P$. salmonis with that of phylogeneticallyrelated microorganisms shows that the first
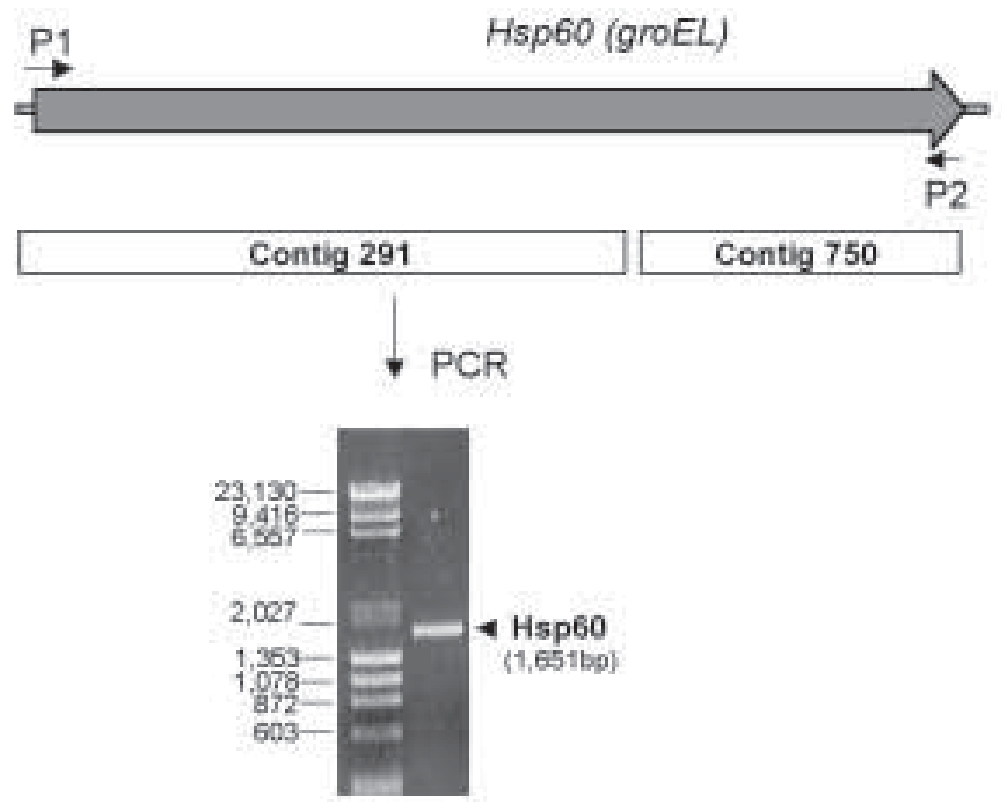

Figure 1. Isolation of the P. salmonis Hsp60 coding region by PCR from genomic $P$. salmonis DNA. The DNA MW ladder is a mixture of Hind III- digested Lambda DNA and Hae III digested ØX174 DNA.

TABLE I

Oligonucleotides used as primers

\begin{tabular}{ll}
\hline Primer & \multicolumn{1}{c}{ Sequence } \\
\hline p1 & 5' -atggagatataagaatg-3' \\
p2 & 5'-ccgcccatgccacccat-3' \\
p3 & 5' -atggctgaaattattggtat-3' \\
p4 & 5' -aacttcttcaaactcagcatc-3' \\
p5 & 5' -gacggatccggagatataagaatgtcagca-3' \\
p6 & 5'-tatgaattcttaaccgcccatgccacccat-3' \\
p7 & 5'-tatgaattcatggctgaaattattggtattg-3' \\
p8 & 5' -gtactcgagctaaacttcttcaaactcagcatc-3' \\
\hline
\end{tabular}


P. salmonta

C. burnetis

F. tularengie

f. poeumophilia

P. aetuginesed

P. salmonta

C. bornetif

F. tolarenisis

I. pretunopitila

P. aerugincsa

P. Sallmonis

c. burnatit

P. Eularengia

I. poeumoplitia

P. neruginesh

P, salmonis

C. burnetif

F. talarenuts

L. poeunophila

P. aeriginosa

P. sazmonts

C. harnetif

5. tularemsis

L. poeumpitila

P. aeruginced

F, sisimonit

c. burnetif

F. tularenaris

L. pneumopitis la

F. aeruginosa

P. salmonfll

c. buxnetif

F. talarensia

4. pneumophila

$P$. aeruginosa

P. entmanfa

C. burneti 1

F. tularensis

L. pneunophila

P. aerivginosa

P. Salmonis

C. harnetis

F. tularensis

L. poeumphil2a

D. aeruginouls

P. easmoni a

c. burnetif

F, tularensis

I. pneumophila

p. aeruginosa

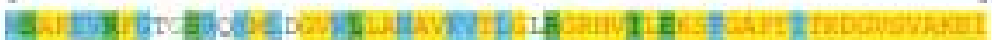

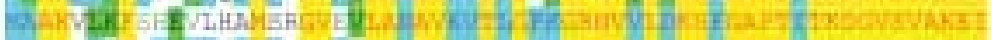

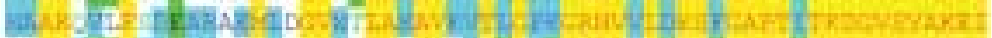

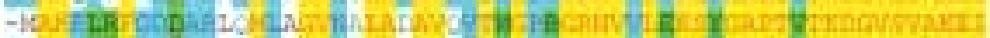

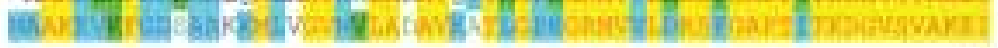

का

1211

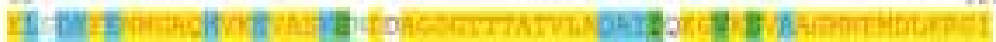

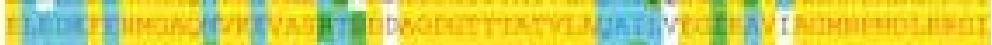

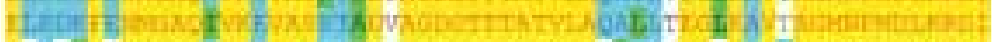

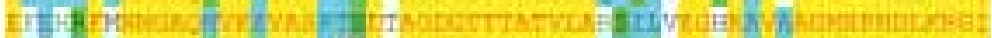

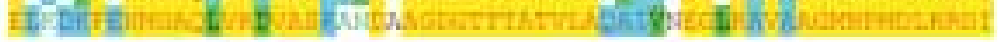
221

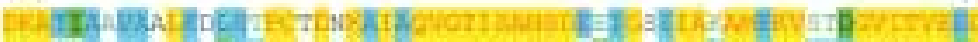

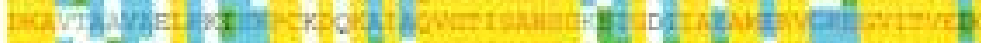

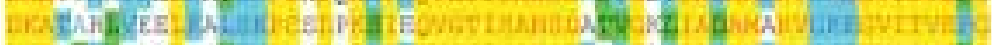

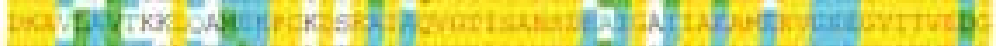

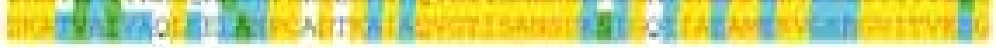

$1 \mathrm{~B}$

240

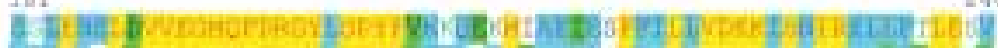

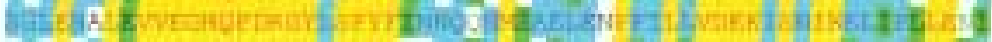

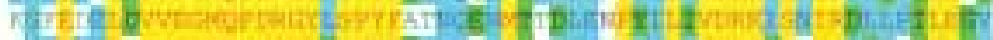
16fili $\mathrm{r}$ -

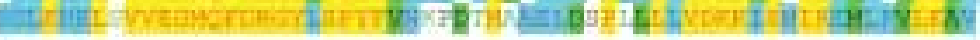

241

sath

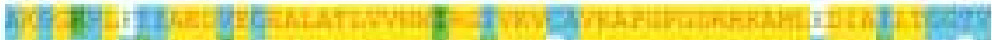

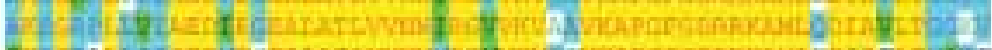

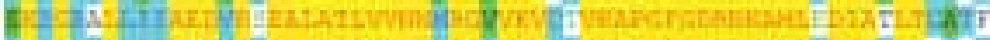

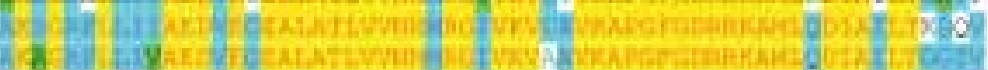

301

160

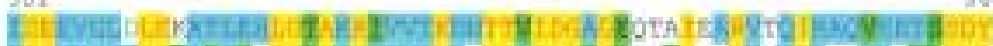

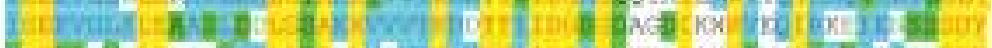
vir to

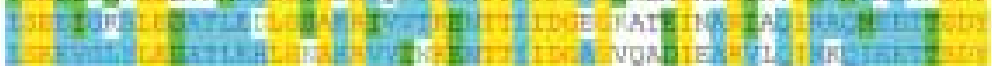

361

420

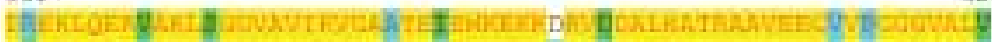

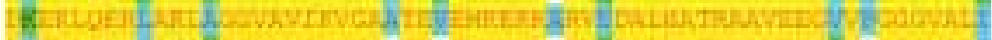
A

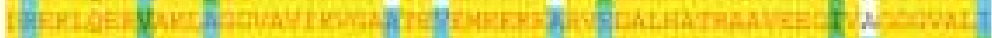

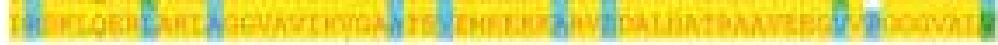

421

480

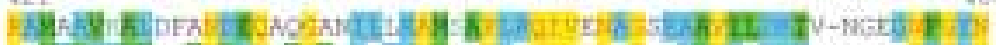

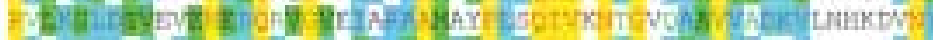

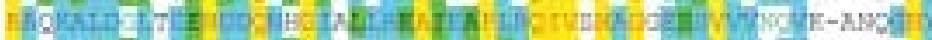

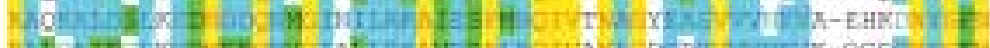

483 a

NTHE aher

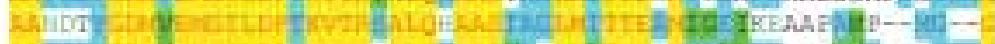

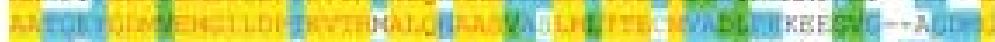

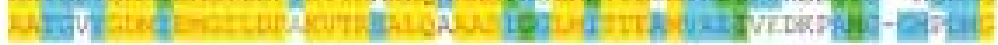

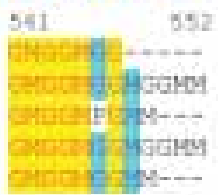

Figure 2. Protein sequence comparison of $P$. salmonis Hsp60 with the corresponding proteins from other bacteria. Multi-alignment was developed by the Vector NTI Suite 6 program. 
lacks a sequence of about 5 amino acids in the carboxyl end, due probably to the incomplete data available of the genomic library.

Approximately $70 \%$ of the region coding for Hsp70 was found in contigs 2130 (595 base pairs), 1687 (619 base pairs) and 1748 (581 base pairs) based on an alignment with Legionella pneumophila (Fig. 3). The Hsp70 gene was amplified using specific primers designed based on the 5' and 3' end sequences of the gene. Primer p3 (Table I) contains the sequence of the first 20 nucleotides of the gene found in contig 2130. The 3' end was not found in the genomic sequence; as a consequence, primer p4 (Table I) was designed using a consensus sequence based on a highly conserved domain in phylogeneticallyrelated species (see Fig. 4). PCR amplification resulted in a fragment of 1920 base pairs, which corresponds to the size of this gene in other microorganisms (Fig. 3). The sequence of the 1920 base pairs fragment codifies a 70,400 dalton protein of 640 amino acids (Fig. 4). The protein shows a high degree of homology with Hsp70 of other microorganisms.

2. Synthesis and characterization of $\mathrm{P}$. salmonis Hsp60 and Hsp70.

In order to characterize Hsp60 and Hsp70 from $P$. salmonis and study their immunogenic properties we proceeded to express in $E$. coli the corresponding recombinant proteins using vector pET32a, in which the cloned genes are expressed as a fusion protein with $E$. coli thioredoxin. For this purpose, the Hsp60 coding region was amplified with primers complementary to the ends of the gene (primers 5 and 6 in Table I) containing the restriction sites BamHI and EcoRI. Primer p6 also contained an extra nucleotide to complete the glycine codon inferred from the consensus sequence for Hsp60 (Fig. 2) and a stop codon. The amplified fragment that codifies an Hsp60 protein 5 amino acids shorter at the carboxyl end in comparison with its homologue in phylogeneticallyrelated species (Fig. 2) was cloned into

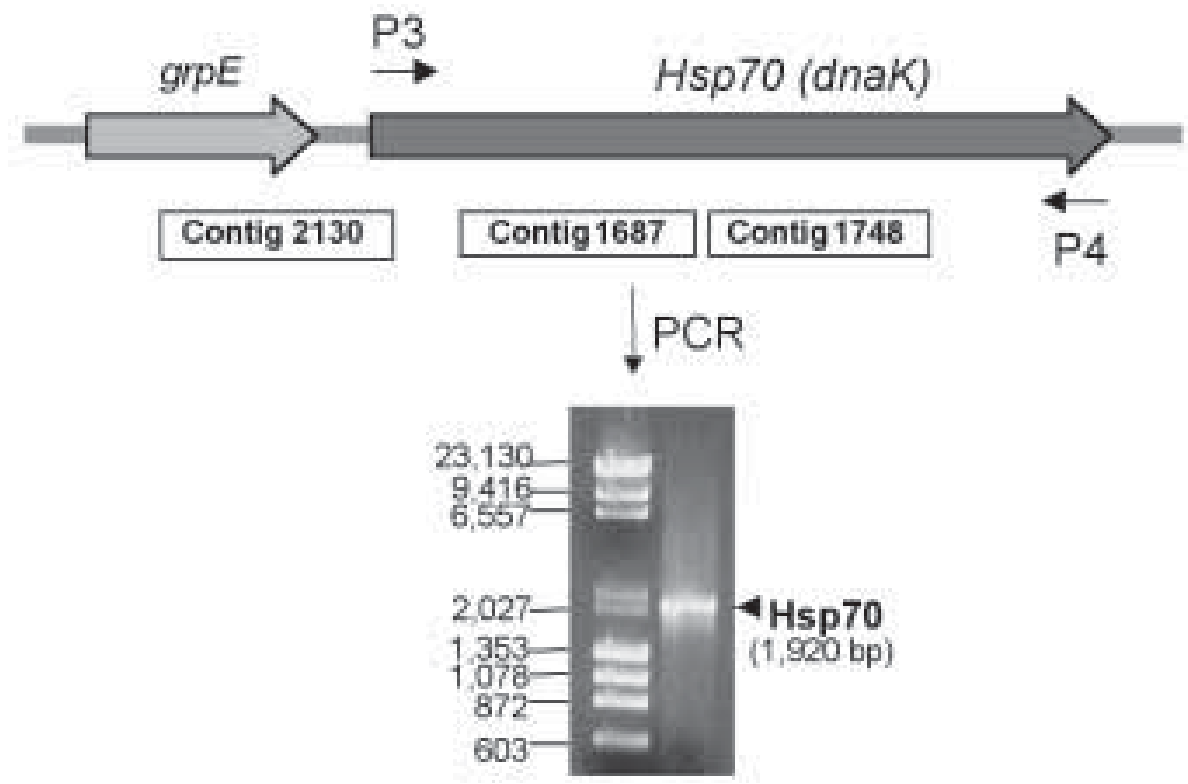

Figure 3. Isolation of the $P$. salmonis Hsp70 coding region by $\mathrm{PCR}$ from genomic $P$. salmonis DNA. The DNA MW ladder is a mixture of Hind III digested Lambda DNA and Hae III digested ØX174 DNA. 
r. mainmis

c. burnerit

2. pnemarnitida

P. aezurinasa

Y. shaterser

2. enlemania

C. Huxinati.

t. presimghis.

$z$, istuginata

Qi rholerate

F, saleminit

c. trumecis

2. sueusyoh.t.

E. Amsutionate

V. efialiatal

F. Aalsatils

f., burnetit

2. priputopidida

F. aezujinose

V. Ihalurae

r. italmartia

C. Burnatid

2. minumahita

$v$. aerugsinase

V. cholerae

2. salewirte

5. imrnesis

2. Ineuvionsis

F. ancurtinate

V. eftelaras

2. solkenis

c. burnecit

2. jusutspinila

$F_{i}$ aerupinans

V. uhrderzas

7. maingmin

C. burnetid

2. mreusphits

P. aecuginase

V, vhnteras

F. *simanta

[5. Eutrintid

2. grewaphis.

r. aerupinats

Q. chofierat

\%. salkande

E. hurnetit

2. mestrnisily

7. - ierujusise

V. =tialintas

E. valontis

C. tuznetit

2. pustisaratidia

e. aecupinago

V. chalerae
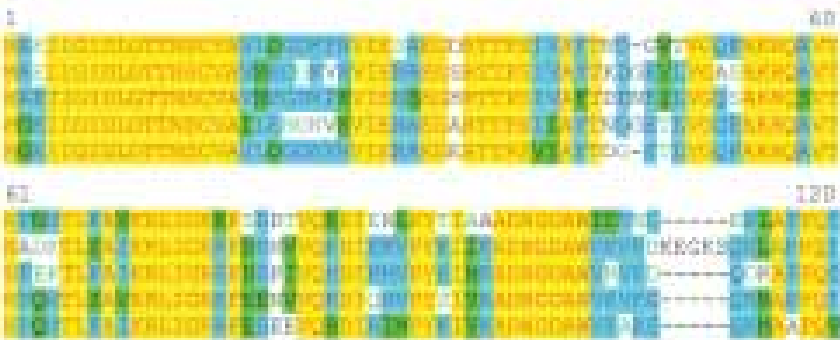

112.

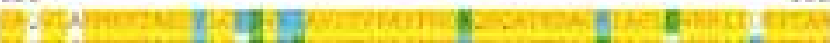

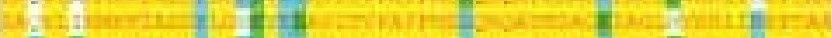

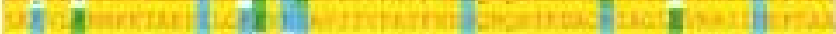
(a)

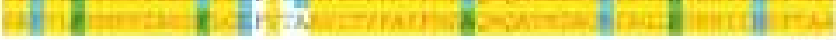

In:

z4ti

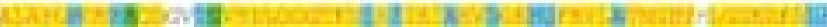

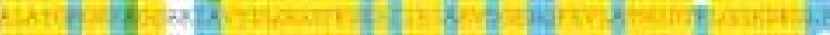

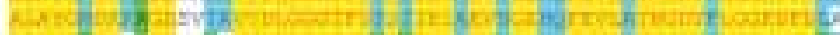

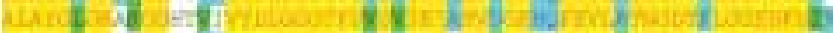

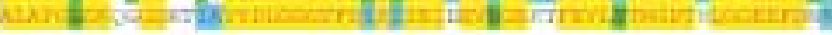

24:

301

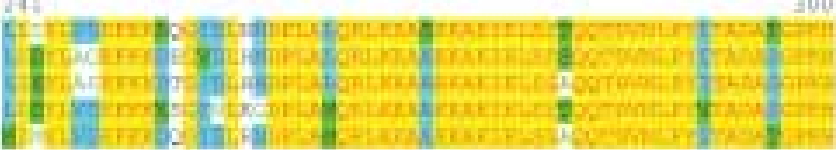

30

36 !

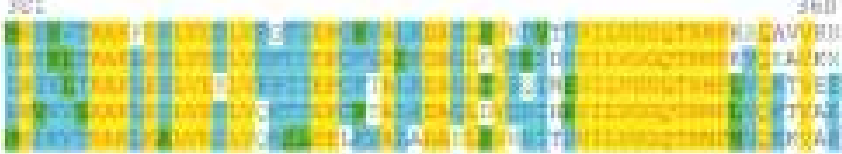

$3 \mathrm{ES}$

421

mourg

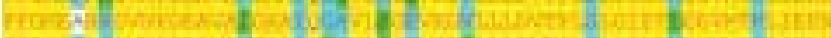

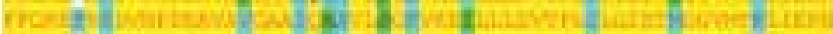

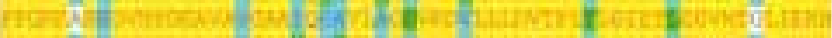

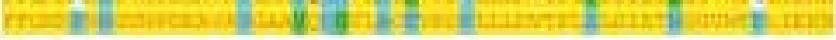

627

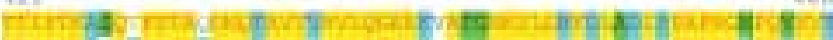

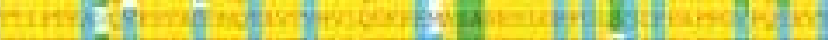

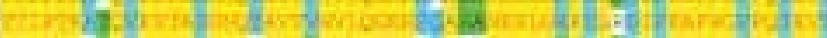

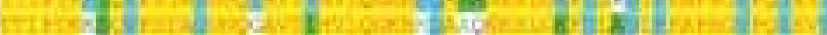

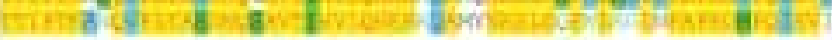
131

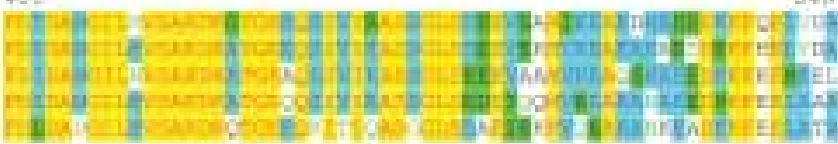

$\leq 4:$

ing

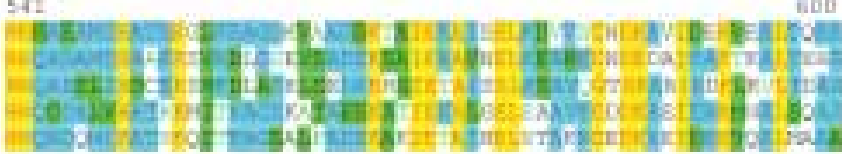

논

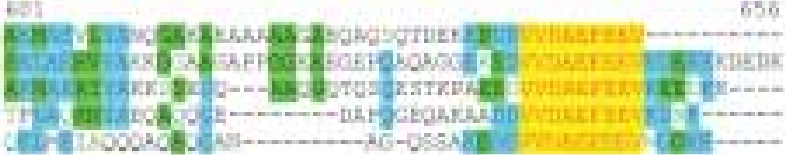

Figure 4. Protein sequence comparison of $P$. salmonis Hsp70 with the corresponding proteins from other bacteria. Multi-alignment was developed by the Vector NTI Suite 6 program. 
pGEM-T and digested with EcoRI and BamH I. The fragment released was ligated to vector pET32a, which was previously digested with the same restriction enzymes. Positive clones were identified by enzymatic digestion. BL21(DE3) cells were transformed with the recombinant vector pET32a-Hsp60 to express the recombinant protein. After a 3-hour induction the recombinant protein was analyzed in a $12.5 \%$ PAGE-SDS gel. The protein of the expected MW ( $80 \mathrm{KDa}$ ) is found in both, the insoluble and the soluble fractions (Fig. $5)$. When necessary, the insoluble fraction was solubilized in 4M urea and the recombinant Hsp60 purified in an affinity column with $\mathrm{Ni-agarose}$ resin under denaturating conditions (Fig. 5).

The procedure followed for the gene encoding Hsp70 is in essence the same one used for Hsp60. The Hsp70 coding region was amplified from the genome of $P$. salmonis with primers 7 and 8 (Table I), complementary to the ends of the gene and containing the restriction sites EcoRI and XhoI respectively and a stop codon. The amplified fragment was cloned into pGEM-T and later subcloned in pET32a. E. coli BL21 (DE3) cells transformed with pET32a-Hsp70 were induced to express the recombinant protein for 3 hours, and the recombinant protein was analyzed in a $12.5 \%$ PAGE-SDS gel. The protein is primarily found in the soluble protein fraction. The recombinant protein was purified using a nickel-agarose resin to approximately $85 \%$ of purity (Fig. 5).

3. Detection of Hsp60 and Hsp70 in P. salmonis cultured in cell lines.

A good vaccine candidate is expected to be expressed during host infection by the pathogen. In an attempt to determine whether the genes coding for Hsp60 and Hsp70 were expressed during the replication of $P$. salmonis inside the host cells, CHSE
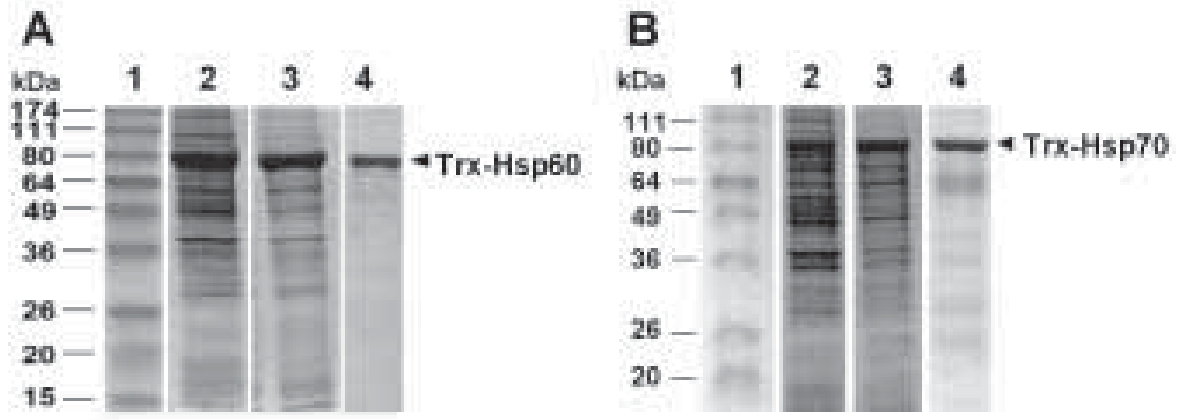

Figure 5. SDS-PAGE analysis of the expression in E. coli and purification of $P$. salmonis Hsp60 and Hsp70 fusion proteins.

A: Lane 1: Molecular weight markers. Lane 2: $10 \mu \mathrm{g}$ of insoluble protein fraction of recombinant BL21(DE3)/pET32-Hsp60 cells after 3 hours of induction with IPTG. Lane 3: $10 \mu \mathrm{g}$ of soluble protein fractions of recombinant BL21(DE3)/pET32-Hsp60 cells after 3 hours of induction with IPTG. Lane 4: Purified Trx-Hsp60 recombinant protein after Ni-agarosa purification.

B: Lane 1: Molecular weight markers. Lane 2: $10 \mu \mathrm{g}$ of insoluble protein fraction of recombinant BL21(DE3)/pET32-Hsp70 cells after 3 hours of induction with IPTG. Lane 3: $10 \mu \mathrm{g}$ of soluble protein fraction of recombinant BL21(DE3)/pET32-Hsp70 cells after 3 hours of induction with IPTG. Lane 4: Purified Trx-Hsp70 recombinant protein after Ni-agarosa purification. 
cells infected with $P$. salmonis were cultured until a $90 \%$ cytopathic effect was achieved; the bacteria was then harvested as described in Methods. Whole-cell P. salmonis protein was analyzed by Western blot with monoclonal antibodies produced in mice against the recombinant proteins Trx-Hsp60 and Trx-Hsp70. The specificity of the monoclonal antibodies for Hsp60 and Hsp70 was previously confirmed by ELISA and Western blot against each recombinant protein respectively (data not shown). These antibodies recognized the recombinants excised from the thioredoxin fusion peptide with enterokinase, confirming their specific interaction with the target. The Western blot in Figure 6 shows the presence of Hsp60 and Hsp70 in P. salmonis cultured in the CHSE cell line. The detected proteins migrate according to the expected size of the native proteins. The mouse antibodies elicited by the recombinant proteins appear specific for the $P$. salmonis heat shock proteins and has no cross reactivity with the eukaryotic counterparts since the monoclonal antibodies do not react with proteins of non-infected CHSE cells (data not shown).

The high expression of Hsp60 and Hsp70 detected in $P$. salmonis is coincident with the strong production of these proteins described for other intracellular bacteria during infection (Fernández et al, 1997). In contrast to their cytoplasmic location in most bacteria and eukaryotes, Hsp60 and Hsp70 have been detected in pathogenic bacteria in the periplasm, on bacterial surfaces, and sometimes as extracellular secreted proteins during host infection (Garduño et al., 1998; Scorpio et al., 1994; Gillis et al., 1985). No leader sequences or other recognizable motif

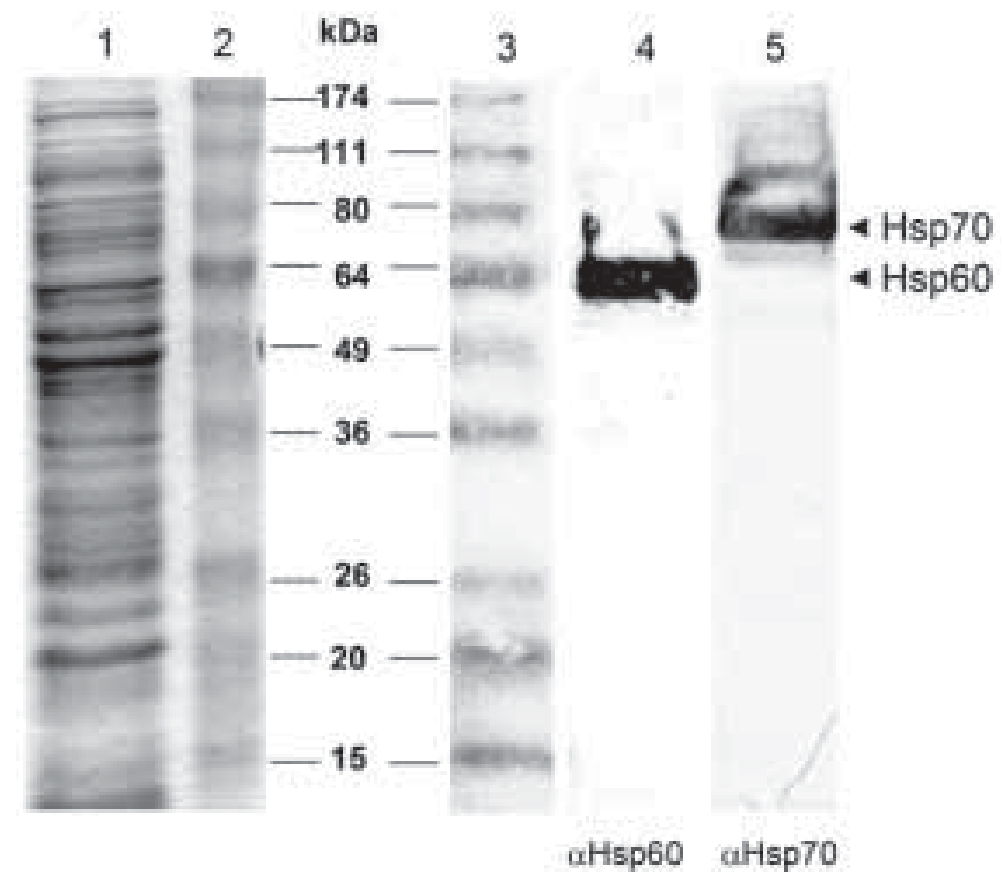

Figure 6. Western blot of Hsp60 and Hsp70 present in $P$. salmonis.

Gel was loaded with $30 \mu \mathrm{g}$ of whole-cell P. salmonis protein and the blotted membrane was analyzed with a 1:200 dilution of each monoclonal antibody. 1: Coomasie blue staining of $P$. salmonis lysate. 2 and 3: Molecular weight markers. 4: Membrane analyzed with a monoclonal antibody against Hsp60. 5: Membrane analyzed with a monoclonal antibody against Hsp70. 
that suggest a secretory role are present in the chaperonin proteins, raising the possibility of a unique specific transport mechanism for Hsp in these pathogens. The surface location of Hsp has been linked to a significant role in mediating attachment and invasion of host cells as well as immune modulation activities (Ensgraber and Loos, 1992; Huesca et al., 1996; Retzlaff et al., 1994; Hoffman and Garduño, 1999).

4. Immunogenic properties of the $P$. salmonis Hsp60 and Hsp70.

Immunogenic reactivity of $P$. salmonis Hsp60 and Hsp70 was studied by the Western Blot technique using a polyclonal rabbit serum developed against an extract of
P. salmonis obtained from a cell culture. Figure 7 shows that both recombinant proteins are recognized by the antiserum against $P$. salmonis. This result confirms that native Hsp60 and Hsp70 expressed during the intracellular life cycle of $P$. salmonis are immunogenic in rabbits. We also found that serum from Atlantic salmon that had been immunized three months earlier with a formulation containing the two recombinant Hsp reacted with the fusion Trx-Hsp60 and Trx-Hsp70. This was analyzed by ELISA (Fig. 8) and Western blot (Fig. 9A). To confirm that fish serum recognized epitopes of the Hsp and was not merely reacting against the thioredoxin fusion protein, the serum was also tested by Western blot against recombinant Hsp60 and Hsp70 not

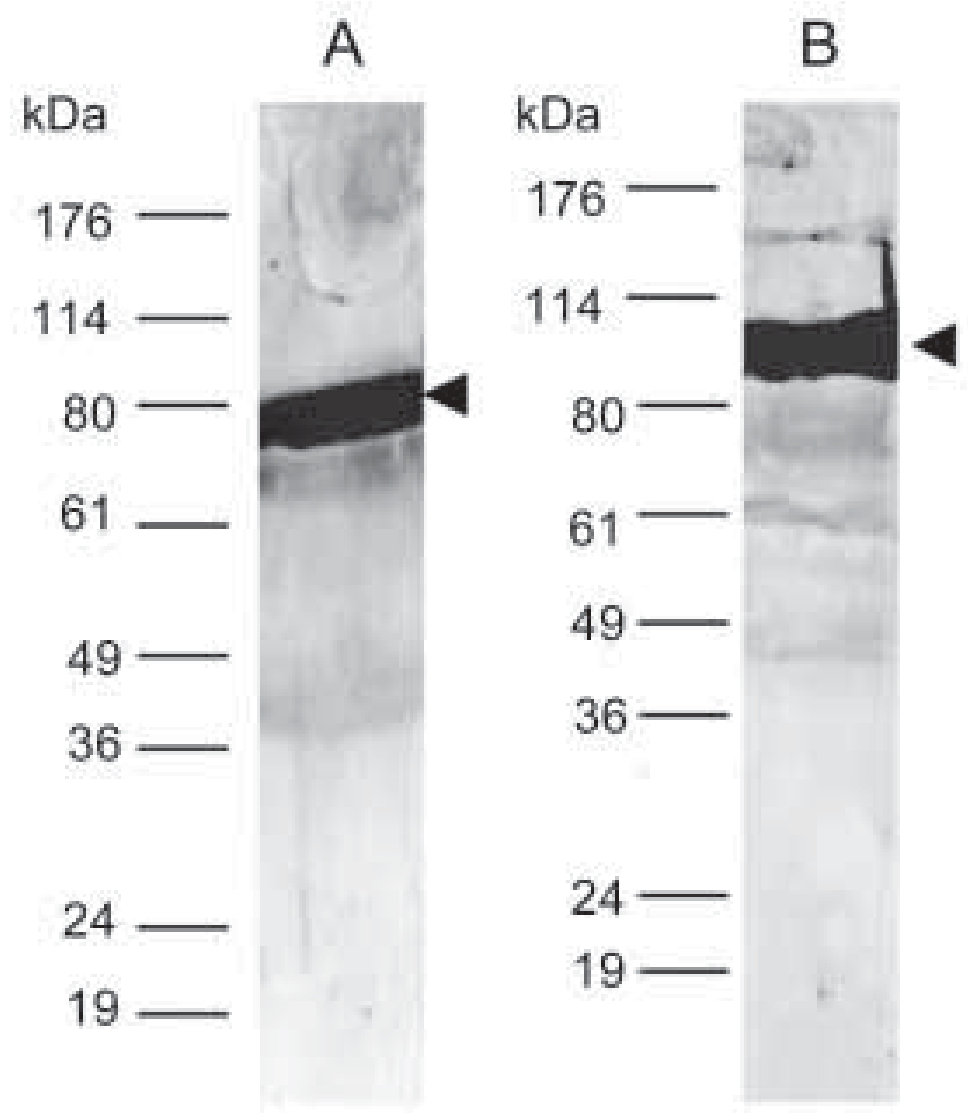

Figure 7. Western blot analysis of recombinant Hsp60 and Hsp70 with anti $P$. salmonis serum.

A: Trx-Hsp60 tested with a 1:1000 dilution of $P$. salmonis polyclonal serum.

B: Trx-Hsp70 tested with a 1:1000 dilution of P. salmonis polyclonal serum. 

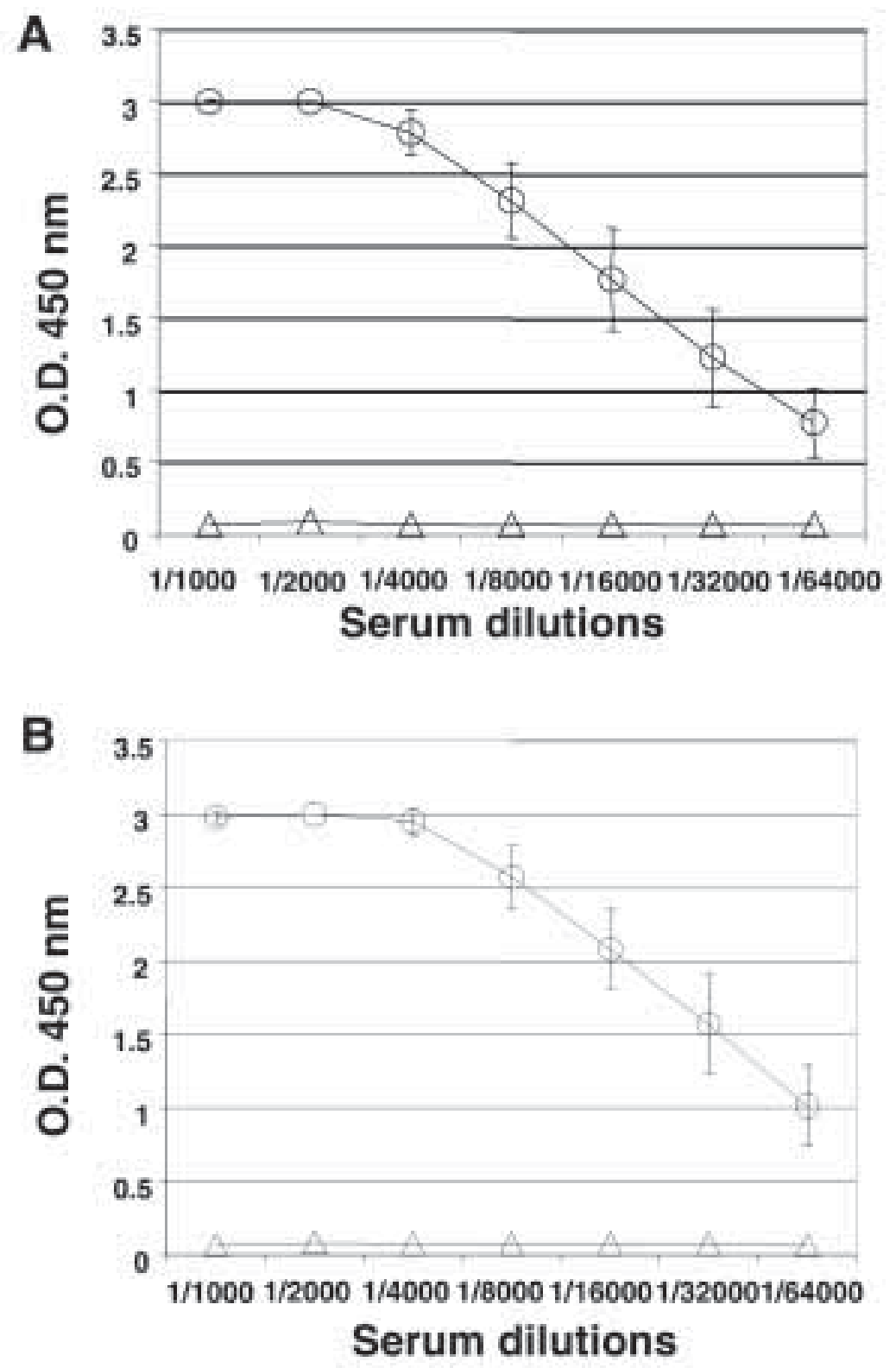

Figure 8. Measurement of antibodies to Trx-Hsp60 and Trx-Hsp70 in serum of salmon immunized with both recombinant proteins.

A: ELISA analysis of antibodies against Hsp60 in immunized $(\bigcirc)$ and control fish $(\Delta)$.

B: ELISA analysis of antibodies against Hsp70 in immunized $(\bigcirc)$ and control fish $(\Delta)$. 

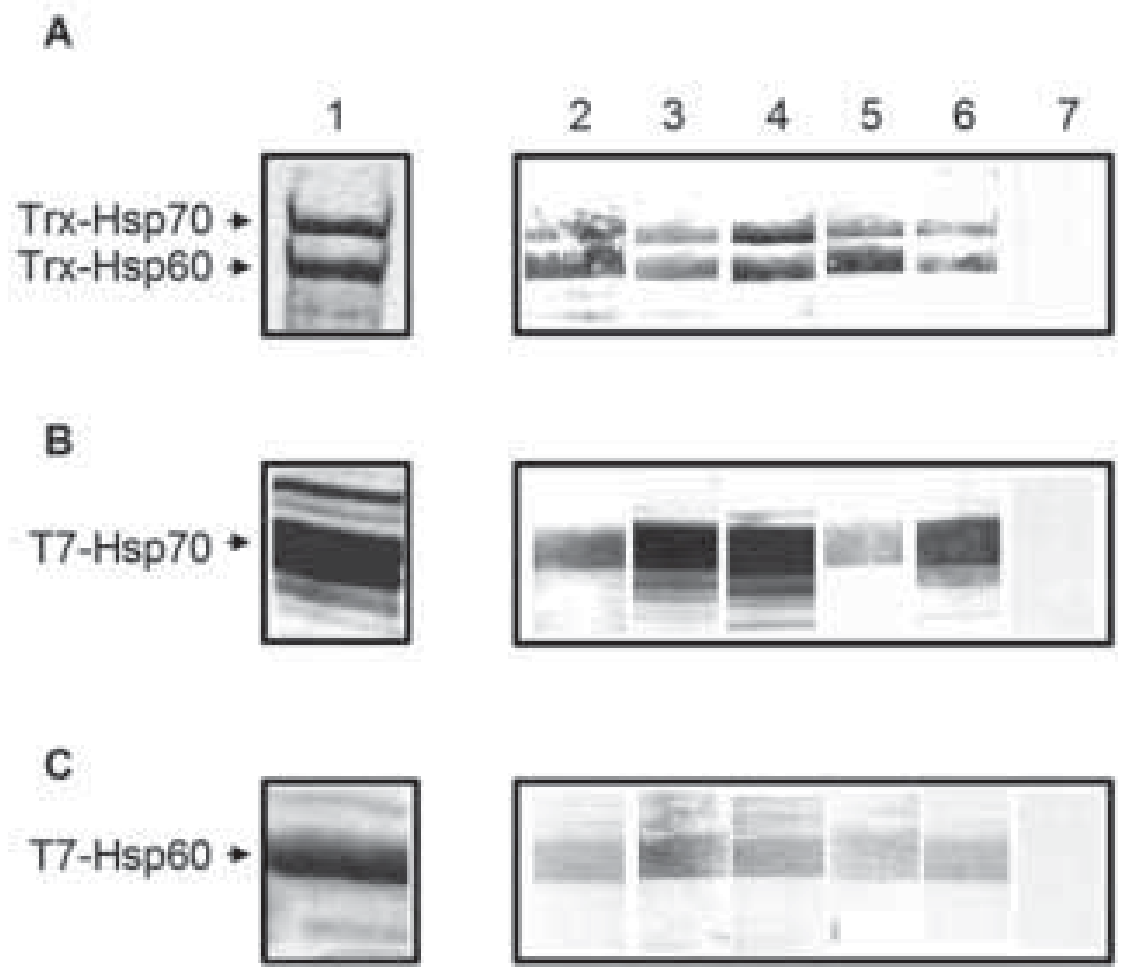

Figure 9. Western blot analysis of serum obtained from salmon immunized with recombinant Hsp60 and Hsp70.

A: Lane 1: Electrophoretic pattern of a mixture of purified Trx-Hsp60 and Trx-Hsp70; Lanes 2-6: blots tested with serum of immunized fish; Lane 7: blot tested with serum of non-immunized fish.

B: Lane 1: Electrophoretic pattern of whole-cell extract containing recombinant T7-Hsp70; Lanes 2-6: blots tested with serum of immunized fish; Lane 7: blot tested with serum of non-immunized fish.

C: Lane 1: Electrophoretic pattern of whole-cell extract containing recombinant T7-Hsp60; Lanes 2-6: blots tested with serum of immunized fish; Lane 7: blot tested with serum of non-immunized fish.

fused to thioredoxin obtained by expression with vector pET21a (Fig. 9B and 9C). The recognition of both recombinants confirmed that $P$. salmonis Hsp60 and Hsp70 are immunogenic in salmon and thus are bonafide antigens to be included in an experimental vaccine to study their ability to protect against $P$. salmonis infection.

5. Protection against $\mathrm{P}$. salmonis in vaccinated Atlantic salmon.

One tank containing vaccinated and control non-injected fish was challenged with $P$. salmonis 625 degree days after immunization with the formulation that contained recombinant Hsp60 and Hsp70. A group of adjuvant-injected fish was also included in the trial as control. At day 21 after $P$. salmonis infection, control fish started to die and cumulative mortality increased dramatically during the next 20 days. In contrast, a reduced number of vaccinated fish died during this period, achieving a relative percent survival (RPS) of $89.6 \%$ at the end of the challenge (Table II). The strong protective response elicited by the recombinant formulation contrast 
TABLE II

Protective response of immunized salmon to $P$. salmonis

\begin{tabular}{|c|c|c|c|c|}
\hline \multirow{3}{*}{ Group } & \multicolumn{4}{|c|}{ Challenge } \\
\hline & \multicolumn{2}{|c|}{30 days } & \multicolumn{2}{|c|}{50 days } \\
\hline & Mortality & RPS & Mortality & RPS \\
\hline V1 & $8 \%$ & 82.6 & $8 \%$ & 89.6 \\
\hline V0 & $58 \%$ & -26 & $69 \%$ & 10.4 \\
\hline Control & $46 \%$ & & $77 \%$ & \\
\hline RPS & \multicolumn{4}{|c|}{$=$ Relative percent survival } \\
\hline Control & \multicolumn{4}{|c|}{$=$ Non-injected fish } \\
\hline V0 & \multicolumn{4}{|c|}{$=$ Adjuvant-injected fish } \\
\hline V1 & \multicolumn{4}{|c|}{$=$ Fish injected with recombinant proteins } \\
\hline
\end{tabular}

with the weak protection that has been described for bacterins against $P$. salmonis (Smith et al., 1997) and is coincident with the protective effect elicited by Hsp60 and Hsp70 in other animal models (Ferrero et al., 1995; Gómez et al., 1995). In conclusion our data strongly supports the use of Hsp60 and Hsp70 as antigens in a recombinant vaccine against the intracellular pathogen Piscirickettsia salmonis.

\section{REFERENCES}

AGUAYO J, MIQUEL A, ARANKI N, JAMETT A, VALENZUELA PD, BURZIO LO (2002) Detection of Piscirickettsia salmonis in fish tissues by an enzymelinked immunosorbent assay using specific monoclonal antibodies. Dis Aquat Organ 49: 33-38

BINDER S (1995) Mitochondrial nucleic acid purification and analysis. Methods Mol Biol 49: 383-389

BRANSON EJ, NIETO DÍAZ-MUÑOZ D (1991) Description of a new disease condition occurring in farmed coho salmon, Oncorhynchus kisutch (Walbaum) in South America. J Fish Dis 14: 147156

BROCKLEBANK JR, EVELYN TPT, SPEARE DJ, ARMSTRONG RD (1993) Rickettsial septicaemia in farmed Atlantic and Chinook salmon in British Columbia: Clinical presentation and experimental transmission. Can Vet J 34: 745-748

ENSGRABER M, LOOS M (1992) A 66-kilodalton heat shock protein of Salmonella typhimurium is responsible for binding of the bacterium to intestinal mucus. Infect Immun 60: 3072-3078

FERNÁNDEZ RC, LOGAN SM, LEE SH, HOFFMAN PS (1997) Elevated levels of Legionella pneumophila stress protein Hsp60 early in infection of human monocytes and L929 cells correlate with virulence. Infect Immun 64: 1968-1976

FERRERO RL, THILBERGE JM, KANSAU I, WUSCHER N, HUERRE M, LABIGNE A (1995) The GroES homolog of Helicobacter pylori confers protective immunity against mucosal infection in mice. Proc Natl Acad Sci USA 92: 6499-6503

FRYER JL, LANNAN CN, GARCÉS LH, LARENAS JJ, SMITH PA (1990) Isolation of a rickettsia-like organism from diseased coho salmon (Oncorhynchus kisutch) in Chile. Fish Pathol 25: 107-114

FRYER JL, MAUEL MJ (1997) The Rickettsia: an emerging group of pathogens in fish. Emerg Infec Dis 3: $137-144$

GARDUÑO R, FAULKNER G, TREVORS MA, VATS N, HOFFMAN P (1998) Immunolocalization of Hsp60 in Legionella pneumophila. J Bacteriol 180: 505-513

GILLIS TP, MILLER RA, YOUNG DB, KHANOLKAR DR, BUCHANAN TM (1985) Immunochemical characterization of a protein associated with Mycobacterium leprae cell wall. Infect Immun 49: 371377

GÓMEZ FJ, ALLENDOERFER R, DEEPE GS JR (1995) Vaccination with recombinant heat shock protein 60 from Histoplasma capsulatum protects mice against pulmonary histoplasmosis. Infect Immun 63: 2587-2595

HOFFMAN PS, GARDUÑO RA (1999) Surface-associated heat shock proteins of Legionella pneumophila and Helicobacter pylori: roles in pathogenesis and immunity. Infect Dis Obstet Gynecol 7: 58-63

HOUSE ML, BARTHOLOMEW JL, WINTON JR, FRYER JL (1999) Relative virulence of three isolates of Piscirickettsia salmonis for coho salmon Oncorhynchus kisutch. Dis Aquat Organ 35: 107-113

HUESCA M, BORGIA S, HOFFMAN P, LINGWOOD CA (1996) Acidic $\mathrm{pH}$ changes receptor binding specificity of Helicobacter pylori: a binary adhesion model in which surface heat shock (stress) proteins mediate sulfatide recognition in gastric colonization. Infect Immun 64: 2643-2648

JAMETT A, AGUAYO J, MIQUEL A, MÜLLER I, ARRIAGADA R, BECKER MI, VALENZUELA P, BURZIO LO (2001) Characteristics of monoclonal antibodies against Piscirickettsia salmonis. J Fish Dis 24: $205-215$

JONES SR, MACHAM RJ, GROMAN DB, CUSACK RR (1998) Virulence and antigenic characteristics of a cultured Rickettsia-like organism isolated in farmed Atlantic salmon Salmo salar in eastern Canada. Dis Aquat Organ 33: 25-31

KAUFMAN SHE (1990) Heat shock proteins and the immune response. Immunol Today 11: 129-136

KAUFMAN SHE (1991) Heat shock proteins and pathogenesis of bacterial infection. Springer Semin. Immunopathol 13: 25-36

KAUFMAN SHE, SCHOOL B, WANDWÜRTTENBERGER A, STEINHOFF U, MUNK ME, KOGA T (1990) T-cells, stress proteins and pathogenesis of mycobacterial infections. Curr Top Microbiol Immunol 155: 125-141

KÖHLER G, MILSTEIN C (1975) Continuous cultures of fused cells secreting antibody of predefined specificity. Nature (London) 256: 495-497

LAEMMLI UK (1970) Cleavage of structural proteins during the assembly of the head of bacteriophage T4. Nature 227: 680-685

LANNAN CN, FRYER JL (1993) Piscirickettsia salmonis, a major pathogen of salmonid fish in Chile. Fish Res 17: $115-121$

MIQUEL A, MÜLLER I, FERRER P, VALENZUELA PDT AND BURZIO LO (2003) Immunoresponse of Coho salmon immunized with a gene expression library from Piscirickettsia salmonis. Biol Res 36: 313-323

RETZLAFF C, YAMAMOTO Y, HOFFMAN PS, FRIEDMAN H., KLEIN TW (1994) Bacterial heat 
shock proteins directly induce cytokine mRNA and interleukin-1 secretion in macrophage cultures. Infect Immun 62: 5689-5693

SANGER F, NICKLEN S, COULSON AR (1977) DNA sequencing with chain terminating inhibitors. Proc Natl Acad Sci USA 74: 5463-5467

SCORPIO A, JOHNSON P, LAQUERRE A, NELSON DR (1994) Subcellular localization and chaperone activities of Borrelia burgdorferi Hsp60 and Hsp70. J Bacteriol 176: 6449-6456

SMITH PA, CONTRERAS JR, LARENAS JJ, AGUILLÓN JC, GARCES LH, PÉREZ B, FRYER JL (1997) Immunization with bacterial antigens: Piscirickettsiosis. Dev Biol Stand 90: 161-166

TOWBIN H, STAEHELIN T, GORDON J (1979) Electrophoretic transfer of proteins from polyacrylamide gels to nitrocellulose sheets: procedure and some application. Proc Natl Acad Sci USA 76: 4350-4354

WILHELM V, VILLEGAS J, MIQUEL A, ENGEL E, BERNALES S, VALENZUELA PDT, BURZIO LO (2003) The complete sequence of the mitochondrial genome of the Chinook salmon, Oncorhynchus tshawystscha. Biol Res 36: 223-231

WILHELM V, MORALES C, MARTÍNEZ R, ROSEMBLATT M, BURZIO LO, VALENZUELA PDT (2004) Isolation and expression of the genes coding for the membrane bound transglycosylase $\mathrm{B}$ $(\mathrm{MltB})$ and the transferring binding protein $\mathrm{B}(\mathrm{TbpB})$ of the salmon pathogen Piscirickettsia salmonis. Biol Res 37: 783-793

ZÜGEL U, KAUFMAN SHE (1999) Role of heat shock proteins in protection and pathogenesis of infectious diseases. Clin Microbiol Rev 12: 19-39 